\title{
How elite sport helps to foster and maintain a neoliberal culture: The 'branding' of Melbourne, Australia
}

\author{
Alistair John \\ Life Sciences, Brunel University London, UK
}

\section{Brent McDonald}

Institute for Health and Sport, Victoria University, Australia

\begin{abstract}
This article explores the role that elite sport has played in the State Government of Victoria's (Australia) neoliberal agenda of creating an environment conducive to commercial activity. Adopting an urban entrepreneurial approach of selling the 'city' as an attractive place for crossborder investment, the state government has strategically invested public funds into major sporting events in Melbourne. Four specific sporting events were examined: i) construction and redevelopments of 'Melbourne Park' to host the Australian Open Tennis Championships; ii) hosting the 2006 Commonwealth Games; iii) acquisition of the Australian Formula One Grand Prix and continued political, corporate and media support for the event; and iv) construction of an urban football stadium. Newspaper reports and parliament transcripts between 1984 and 2014 were collected to highlight issues of contest in the 'sport city' in conjunction with a thematic analysis of interviews with influential cultural producers of the 'sport city' - most notably state premiers, members of parliament, CEOs of public sports trusts and newspaper journalists. Findings illustrate that the Victorian state has successively re-regulated a neoliberal urban entrepreneurial strategy, often preventing dissident groups from resisting neoliberal activities, and that in Melbourne sport operates as 'cultural glue' to establish the logic of neoliberalism in an embodied sense.
\end{abstract}

\section{Keywords}

cultural glue, Melbourne, neoliberal, sport city, urban entrepreneurialism 


\section{摘要}

本文探讨了精英体育在（澳大利亚）维多利亚州政府新自由主义议程中所起的作用, 该 议程旨在创造有利于商业活动的环境。采用将 “城市” 作为对跨境投资的有吸引力的地 方出售的城市创业思路, 州政府战略性地将公共资金投入墨尔本的重大体育赛事。我们 研究了四项具体的体育赛事：i）为举办澳大利亚网球公开赛建设和重建 “墨尔本公园”; ii）主办2006年英联邦运动会; iii）收购澳大利亚一级方程式大奖赛, 并继续为该赛事提 供政府、企业和媒体支持; iv）建造一座城市足球场。我们收集了1984年至2014年期间 的报纸和议会记录, 以突出围绕 “体育城市” 的争论话题, 与此相结合, 我们对有影响 力的 “体育城市” 文化生产者（主要是历任州长、议会成员、公共体育信托和的首席执 行官报纸记者）的访谈进行了主题分析。我们的研究结果表明, 维多利亚州已经陆续地 将新自由主义的城市创业战略法规化，通常这会阻止持不同政见的团体抵制新自由主义 活动, 并且, 在墨尔本, 体育运动作为 “文化粘合剂” , 是支持新自由主义理念的一种 有形表达。

\section{关键词}

文化粘合剂、墨尔本、新自由主义、体育城市、城市创业精神

Received September 2017; accepted December 2018

\section{Introduction}

The last three decades have witnessed an increasing use of elite sport, by advanced and emerging states, for a range of urbanrelated activities including urban renewal (Gold and Gold, 2008), soft power (Grix and Houlihan, 2014) and state branding (Hall, 2006). The decision to invest in sport has been framed by an urban entrepreneurial approach to governance that supports a policy agenda of using public resources to present the city as 'liveable' and an ideal location for capital investment under the guise that wider benefits for the state will be achieved (Harvey, 1989). In order to regulate this sporting urban entrepreneurial strategy, governments have often bypassed public consultation and employed mechanisms - specifically anti-protest laws - which control the public's ability to organise resistance (Lowes, 2004; Watt, 2013). In addition to being a vehicle for urban entrepreneurialism, sport serves as a site where neoliberal ideas and beliefs are practised and promoted (Coakley, 2011a). As such, the escalating political decisions to interpret elite sport as a 'public good', combined with the normalisation of neoliberal ideology that is taught through sport, make it not just a cultural activity worthy of scholarly attention but also one worthy of political activism.

Melbourne, a self-proclaimed and industryawarded 'sport city' (The Age, 2010; Premier of Victoria, 2016), serves as an ideal site for examining the role of sport in supporting this neoliberal agenda. In this article we argue that the Victorian state's strategic investment of public resources into elite sport over the past three decades firstly is indicative of the embracement of a neoliberal agenda and secondly serves to strengthen the logic of neoliberalism by (re)constructing a culture which accepts and naturalises the neoliberal processes associated with sport. The aim of this article is to outline the role of sport as a mechanism for promoting the 'trope of individual responsibility' (Wacquant, 2010) which has supported the Victorian Government's neoliberal agenda of creating an environment (social, cultural and physical) conducive to commercial activity. 
We begin by conceptualising neoliberalism and the role of sport as a reflection and driver of neoliberal practices. Following, we present the context of Melbourne and our methodology. We then explain, through four themes, the use of elite sport in constructing an environment conducive to, and reflective of, neoliberal activities. Finally, we illustrate the capacity of sport to operate as 'cultural glue'; that is, sport's ability to 'work' through individual bodies and establish the logic of neoliberalism in an embodied sense.

\section{Neoliberalism}

We employ a Bourdieusian approach to examining Melbourne by conceptualising the bureaucratic state as the 'repository of all the universal ideas associated with the idea of the public' (Bourdieu, 1998a: 102, emphasis in the original), or as the central bank of symbolic capital (Wacquant, 2004a), which shapes and defines society. Within the state, power struggles occur as agents contest for the legitimacy to distribute and redistribute public resources within the bureaucratic field (Wacquant, 2014). Neoliberalism is understood here as more than merely an economic policy model, but rather as an economic, cultural and political project to 'reengineer the state' (Hilgers, 2011; Jessop, 2013; Wacquant, 2010, 2012, 2014). Specifically, we follow Loïc Wacquant's (2010, 2012, 2014) conceptualisation that neoliberalism involves imprinting market-like mechanisms on everyday life in combination with the retraction of the Fordist-Keynesian welfare safety-net and incorporation of disciplinary 'workfare' policies, increasing penalisation to contain disorder and re-asserting the authority of the state whilst advocating individual responsibility.

Neoliberal post-industrial cities, open to the framework of deregulation and devotion to market rules, have engaged in the 'zerosum inter-urban competition for resources, jobs and capital' (Harvey, 1989: 5), replacing warehouses and manufacturing with the 'managerial and administrative arms of the public and private sectors' (Winter and Brooke, 1993: 264). Urban geographers have labelled the strategy of presenting the city to multinational corporations as an ideal location for capital investment as 'urban entrepreneurialism' (Harvey, 1989). This urban entrepreneurial strategy has resulted in an ideological shift in the role of government, away from local and welfare provision and towards economic growth (Hubbard, 1996).

\section{Neoliberalism and sport}

The role of sport as a reflection, or driver, of neoliberalism has been illustrated by a number of scholars. Miller (2012: 24) articulates the link: 'Sport is [neoliberalism's] most spectacular embodiment, through the dual fetish of competition and control, individualism and government.' Coakley (2011a: 75) asserts that sport often serves to reaffirm 'a belief in competition as the primary basis for assessing merit and allocating rewards'. As such, an ideology that perpetuates the notion that 'economic winners deserve power and privilege' while 'economic failure is due to poor choices or weak character' is constructed (Coakley, 2011a: 75). The composition of sport (in the general sense) is centred on the logic of individual responsibility and competition. In addition, elite sports teams and athletes provide a vehicle for corporations to inject into public discourse messages promoting consumption as a lifestyle' (Coakley, 2011a: 75). Sport therefore embeds neoliberal ideas and beliefs about individual responsibility, competition, the market and consumerism, into popular consciousness (Coakley, 2011a).

Silk and Andrews (2012) highlight the geographical effect of neoliberal policies that include the 'commercialising' of the urban landscape as a place for consumption and 
profiteering; which often consists of building shopping malls, entertainment zones and elite sporting infrastructure. The 'sport city', with a focus on commercialised elite sport, symbolises the valuing of this entertainment cityscape. The Victorian state has played an active role in this spatial shift during the past three decades, supplying much of the sporting infrastructure and redefining public spaces for consumer activity. Moreover, through strategic public investments in elite sport infrastructure, promotion of Melbourne as a 'sport city' and a political discourse which advocates the importance of elite sport to the economic success of the state, the Victorian state has (re)positioned sport as an important element of Victorian culture. This positioning of sport as culturally important has become a form of 'cultural glue'; binding the practices of citizens to the existing neoliberal order (Wacquant, 2012). Wacquant (2010: 213-214) refers to the importance of this cultural glue to the existing neoliberal order, as the paste that binds the 'cultural trope of individual responsibility, which invades all spheres of life' and constructs the entrepreneurial self aligned to the broader 'spread of markets and legitimization for' widening competition whilst simultaneously erasing 'corporate liability'.

Drawing on Hilgers' (2013) understanding that neoliberalism is found in policies, institutions and dispositions, the capacity of sport to operate as cultural glue is threefold. Firstly, sport is understood as a site from which to achieve public good. That is, there exists a belief that sport participation and consumption provide benefits that extend beyond the immediate individual experiences of doing or watching. In the Australian context, sport has been used in an array of policy areas including multiculturalism, social cohesion and security, health, indigenous relations and crime prevention (see, for example, Department of Social Services,
2011; Ministerial Council on Immigration and Multicultural Affairs, 2007). While the faith in sport's transformative and disciplinary power is espoused by sporting evangelists and supported by the bureaucratic field, critical research evaluating such logic seriously questions if any of these alleged benefits are achieved (Coakley, 2011b; Hartmann, 2012; Spaaij, 2012).

At the next level a range of institutions either directly enact, or are driven via the logic of, such policies. Thus, whilst local governments facilitate multicultural sports days or a sport organisation runs a sport intervention programme for 'at risk' youth, the logic embedded in them drives the boom in university courses in sport-related fields, and the unabated funding for Olympic sports. Of course the bureaucratic field that creates Melbourne as the 'sport city' clearly fits in the context of both policy and institution. However, the cultural glue only sticks if it works through individuals, in this case at the level of disposition.

\section{Constructing the 'sport city'}

Similar to many western manufacturing cities, in the early 1970s Melbourne encountered a period of deindustrialisation (Dingle and O'Hanlon, 2009). By the early 1980s, Melbourne was deteriorating, with inner-city business and factory closures resulting in derelict buildings throughout the CBD. In 1984 the Victorian Labor government, under Premier John Cain II, attempted to reverse the effects of deindustrialisation by introducing a 10-year economic strategy, Victoria: The Next Step, which adopted a Keynesianstyle interventionist approach of selecting and investing in Victoria's perceived competitive strengths (Considine and Costar, 1992). One of the nine competitive strengths identified was the national role of Melbourne as a major trading, cultural and sporting centre, and the land-use opportunities to further 
develop that role' (Parliament of Victoria, 1984: 7, emphasis added). While sporting culture has a long history in Victoria (Nadel and Ryan, 2015), we argue that it was Victoria: The Next Step which commenced a more specific use of sport for economic purposes. In the years immediately following, Labor constructed a National Tennis Centre (NTC) to host the Australian Open Tennis Grand Slam and commercial events, submitted a bid for the 1996 Olympic Games and established the Victorian Major Events Company (VMEC); a state-owned company with the explicit remit to acquire major (sporting) events (VMEC, 2015).

Labor's reign ended in 1992 with the election of the Jeff Kennett-led LiberalNational coalition, which employed a strategy of place promotion in an attempt to capture a larger share of investment, jobs and tourism from rival states (Engels, 2000). Kennett adopted a populist political style by using his charisma, simplicity and directness (Canovan, 1999) to convince Victorians that free-market reform along with corporatefriendly laws (Sandercock and Dovey, 2002) would generate capital which would 'trickle down' to the general populace. A co-founder of advertising company KNF, Kennett spent considerable time and resources controlling and manipulating his media profile (Mayne, 2009) and was predominantly supported by the media (White and Economou, 1999). Kennett successfully enticed major (sporting) events with prominent global media broadcasting appeal to the city; most notably conducting secret negotiations to lure the Australian Formula One Grand Prix (F1GP) from Adelaide to Albert Park, Melbourne (Lowes, 2004). Under Kennett the Melbourne Sports \& Aquatics Centre was constructed, as was Docklands Stadium - built on public land with publicly-funded capital infrastructure (Shaw, 2013) - and the NTC was upgraded to secure the Australian Open as a Grand Slam event and make a
2006 Commonwealth Games bid more attractive (Owen and Hansen, 1998).

Subsequent governments, both Labor (1999-2010; 2014-2017) and Liberal-National (2010-2014), retained a similar strategy of 'selling' the city as a desirable place for footloose capital (mobile capital, industry and services that are easily (re)locatable) and cross-border investment (Kroen and Goodman, 2012; Shaw, 2013; Spiller, 2014). Sporting activities since the turn of the century have included hosting the 2006 Commonwealth Games, constructing the Melbourne Rectangular Stadium and upgrading the NTC at an approximate public cost of one billion Australian dollars (Wright, 2012).

In addition to capital investments, the government has contributed to the running/ hosting costs of major sporting events. These have been both annual, such as the Australian Open, the Melbourne (horse) racing carnival and the F1GP, and one-off, such as the 2007 FINA World Swimming Championships, the 2012 UCI Track Cycling World Championships and the 'State of Origin' rugby league matches.

Sport infrastructure and events are increasingly being used by governments across the globe for urban reimagineering and regeneration of 'derelict' areas (Gratton and Henry, 2001; Sam and Hughson, 2011). The desired result is a sanctioned urban space (Silk and Andrews, 2012) that is fortified against perceived dangers to permit consumerism (Schimmel, 2006, 2012). In Melbourne, these spaces have not always been derelict per se; indeed, this may illustrate a point of difference between the Victorian Government's long-term use of sport as a 'branding' tool to entice multinational corporations across the entire city and that of other nations/states/cities. Of concern is that these consumer spaces are frequently created using public money - and with the backing of public authorities - but mostly serve private interests. 


\section{Methodology}

Kellner (2011: 8) insists that 'culture must be studied within the social relations and system through which culture is produced and consumed and that the study of culture is thus intimately bound up with the study of society, politics, and economics'. Locating this study within a cultural studies framework, material was collected across various platforms to capture the social, political, economic and cultural networks which have shaped, produced and consumed the 'sport city’ (Agger, 1992; Kellner, 2011). We position culture as 'the production and circulation of meaning' (Du Gay et al., 1997: 12) and follow du Gay's (1997) 'cultural economy' approach to cultural studies in order to avoid the economic determinism associated with Marxism or overemphasis on the political economy. As such, we acknowledge that economic practices, such as city promotion through urban entrepreneurial activities, 'depend on meaning for their effects and have particular cultural "conditions of existence"” (Du Gay, 1997: 4).

The study was narrowed by restricting the timeframe to after 1984 - the year Victoria: The Next Step was released - with a specific focus on four events:

1. Construction and redevelopments of the National Tennis Centre (NTC),

2. Hosting the 2006 Commonwealth Games,

3. Acquiring and hosting the Australian Formula One Grand Prix (F1GP), and

4. Construction of the Melbourne Rectangular (football) Stadium.

We acknowledge the subjective selection of these events, which was made through a consideration of activities that were 'new' sporting developments in Melbourne, within the study's timeframe, rather than the expansion of existing infrastructure - such as upgrades to the Melbourne Cricket Ground. These four selected events fit within a wider strategy of investing in sport for place making and as such we do not claim that these events in isolation serve to establish the logic of neoliberalism; rather they illustrate some of the neoliberal practices taking place in Melbourne which have strengthened the logic of neoliberalism. We recognise that other notable events occurred during the study timeframe, for example the construction of Docklands Stadium, and recommend future examination of the role of these events in the production of the 'sport city'.

A search of Melbourne's two major daily newspapers (the left-leaning The Age and right-leaning Herald Sun) was undertaken to reconstruct events and highlight issues of contest. We appreciate the limitations, notably media bias, of using newspaper data as a source to represent real world events (Ortiz et al., 2005). As such, in addition to newspaper material we examined transcripts from parliamentary debate to 'check' the reliability of journalist reports and provide additional political voice, while government policy and public audit reports were used to help contextualise the 'political field'.

Finally, 13 semi-structured interviews were conducted with a purposive sample of key decision-makers - including two current MPs, three former premiers, a former treasurer, two former government advisors, a former city councillor and four current or former CEOs of major state sports trusts/ companies. Interview questions revolved around the strategic vision for Melbourne, where sport and major events fit within this vision, barriers to and successes in achieving the vision and the role of public consultation in decision-making processes. In addition to political decision-makers, the president of a prominent F1GP protester group was interviewed to obtain a voice from those who resist major sports events. Lastly, a sports journalist and a former newspaper editor 
were interviewed to gain insight into the media production of the 'sport city'. Access to interviewees was obtained through direct (email and telephone) requests and 'snowballing'. Interviews were transcribed verbatim and thematically analysed by familiarising ourselves with the data, generating initial codes and then searching, reviewing and defining our themes (Braun and Clarke, 2006).

\section{Neoliberalism and the (elite) 'sport city'}

John Brumby, a former Labor premier, explained the rationale for investing in sport as a central tenant of a liveable city:

The desired result ... [you] keep the best and brightest people [and] you attract the best and brightest from around Australia, around the world ... the key [is] ... Melbourne's liveability ... What's liveability? It's the intellectual environment, it's the quality of life environment, it's the content; sport, culture and everything else, and if you get the best people, you'll have the best economy. So the end outcome of that is building a strong economy and a strong quality of life. (J Brumby, personal communication, 11 September 2013)

Brumby's comments encapsulate the urban entrepreneurial approach to governance. That is, the government has tried to promote the 'liveability' of Melbourne to the global labour market in an attempt to procure 'desirable' citizens who will boost the local economy. The approval of neoliberal policies to support this urban entrepreneurial agenda occurs through the ability of the state to redefine the public's interest as to entail government support for economic productivity at the summit in the guise that benefits will 'trickle down' to the wider populace. Indeed, during the timeframe of this study, the Victorian state - particularly during the 1990s under Jeff Kennett - held significant symbolic capital (Wacquant, 2004a) in emphasising the activities of the right hand of the state (Bourdieu, 1998b) related to economic development rather than social welfare, with little resistance from the political opposition (Considine and Costar, 1992; Engels, 2000; John et al., 2013, Lowes, 2004). Four main themes emerged from our analysis of the state's urban entrepreneurial production of Melbourne as 'sport city' over the past three decades: i) the use of public resources for entrepreneurial activities; ii) the representation of domestic and international cities as threats to Melbourne's 'sport city' status; iii) a lack of public consultation; and iv) state regulation to create a corporate-friendly environment. Below, we discuss each of these themes with specific reference to the state's use of elite sport as indicative of an embracement of a neoliberal agenda.

\section{Public resources for elite sport}

Victoria: The Next Step designated sport as one of Melbourne's competitive advantages and, along with the creation of the Victorian Major Events Company, illustrated the state's urban entrepreneurial strategy of encoding Melbourne as a sporting destination during the 1980s. The strategy issued an embracement of private enterprise, with the government re-positioned as the manager of public resources with an overall aim to "promote and stimulate private sector investment and employment' (Holmes, 1995: 11). John Pandazopolous, a Labor MP of over 20 years, explained the significance in designating 'sport' as an investment vehicle for the state:

We were a sport city way before we realised we were a sport city. But having a tag ... made it easy for us to go and reinvest in ... Melbourne Park in recent times as part of an attempt to maintain the Australian Open ... It makes it a 
lot easier for the public then to accept that expenditure versus putting it into schools or hospitals or another road. (J Pandazopolous, personal communication, 17 April 2013)

According to Pandazopolous, the significance of sport to Melbourne had been formalised symbolically and economically through government policy and structure. Furthermore, Pandazopolous' comments are indicative of the state's ability to define elite sport as a pursuit to deliver the urban entrepreneurial agenda. As such, elite sport was re-classified as deserving of public resources.

The investment of public money into elite sport was, in part, justified on the basis of the cultural - and perceived 'biological' importance of sport to Melburnians, as alluded to by two former premiers: 'Sport has always been part of the DNA of Victorians' (J Kennett, personal communication, 6 May 2013); '... it's the culture; it's in the blood of people in Melbourne to want to support events' (J Brumby, personal communication, 11 September 2013). Both explained that valuing sport is ingrained in the citizens of Melbourne and is therefore a legitimate cultural activity to support. Frequent media and political referencing to Melbourne as a 'sport city' or the 'sporting capital' has helped legitimise the use of public resources for elite sporting initiatives and, in doing so, reduces or delimits alternative identities of the city (for example, as the home of the trade union movement) which may challenge the neoliberal agenda. The state's construction of this 'natural' sporting identity has provided an ideal foundation upon which to lay the neoliberal project. That is, the people of Melbourne have consented to sport as a key component of their unique identity and are therefore hesitant to question those activities which enhance this identity.

The physical transformation of public space is a visual representation of the state's market-driven practices associated with neoliberalism. Locating the NTC at Melbourne Park, the temporary use of Albert Park for the F1GP, the alienation of a wedge of Royal Park for the Commonwealth Games Athletes Village and granting corporate sports franchises priority use of open public parkland for training purposes (see Millar, 2005) indicate the state's willingness to appropriate a limited and valued public resource (urban public parkland) in the name of city boosterism and commercialism (John et al., 2013). Notwithstanding some criticism, over the past three decades there has been bipartisan political and media support for major sporting developments in Melbourne (see Herald Sun, 1994, 2006; Houston, 2009; John et al., 2013; Parliament of Victoria, 1985; The Age, 2010). Resistance to elite sport developments in public parks has, instead, emanated from a number of organised protest groups; most notably 'Save Albert Park' (SAP) and the Royal Park Protection Group. SAP president Peter Goad explained that the aim of their group is to:

get rid of all motor racing out of [Albert] park ... We think it's a waste of money and environmentally damaging ... And we also oppose ... any inappropriate development in the park, because it should be retained as public parkland. (P Goad, personal communication, 1 October 2012)

Despite evidence of public opposition to sporting events in public parks, for example an estimated 10,000 F1GP protesters attended an event in 1994 (Neales and Magazanik, 1994), the Victorian state has regulated resistance through the use of anti-protest laws and has bestowed powers for quasi-autonomous non-governmental organisations (quangos) to override heritage, planning and environmental laws (Lowes, 2004; Parliament of Victoria, 2001). Supplementing these laws, commercial media editorials have advocated for the use of public land for entrepreneurial activities while recommending that the citizens of Melbourne trust the government to make decisions in the 
public's best interests: 'Public disquiet over the impact on Albert Park of the Formula 1 Grand Prix is due in part to ignorance of what the Government and organisers intend' (Herald Sun, 1994: 14). In addition to advocating for commercial development within public parks, the media have also devalued the impact of protests by framing protesters as socialists, anti-development (Smith and Whitworth, 1995), selfish (Pro GP, 1994) and 'un-Victorian' (Herald Sun, 2006). In combination, state regulation and media support for events, in a cultural context where opposing sport is regarded as 'un-Victorian', have made resisting commercial sport developments in public spaces challenging.

\section{Urban competition}

The second theme to emerge was the role of external cities/nations posited as rivals in the zero-sum urban entrepreneurial game. These threats have allowed the state to position elite sport as holding significant cultural and economic capital. For example, in the leadup to announcing an upgrade to the NTC in 2010, The Age reported that the government had agreed to a list of demands by Tennis Australia which would result in a renewed 20-year contract to keep the Australian Open in Melbourne until 2036 (Houston, 2009). Included in the demands was a AU\$363 million upgrading and extension of Melbourne Park, as well as Tennis Australia receiving an increased share of Australian Open revenue. Melbourne and Olympic Parks Trust (MOPT) CEO, Brian Morris, explained that:

The previous agreement was due to expire in 2015 and Melbourne was in danger of losing the grand slam event to another state or country ... Discussions with Tennis Australia were brought forward to ensure that the event remained in Melbourne based on its clear economic benefits to Victoria. (B Morris, personal communication, 30 August 2013)
The media reported that Sydney, Shanghai, Madrid and Dubai were interested in the Grand Slam (Higginbottom, 2009; Houston, 2009). These media and political references to rivals' attempts to 'steal' the Grand Slam status of the Australian Open (Rood, 2008; Tennis Australia Magazine, 1983), or the F1GP (Papps, 2000; Pinder, 1993), with little tangible evidence, served to (re)produce the common-sense belief amongst the Melbourne public that there is a need to re-invest in these events and infrastructure and to persist with the urban entrepreneurial strategy.

Hilgers (2013: 81) explains that 'neoliberalism assumes the necessity to intervene; leaders claim the importance of [adaptability] $\ldots$ in order to set up ideal conditions for the market to function'. Claims that rival cities desire the tennis Grand Slam, for instance, permitted the state to justify the necessary 'market-led' changes (including NTC upgrades and reduced share of revenue) to retain the prized asset. Continuing, Hilgers (2013) suggests that the symbolic capital held by the state offers the opportunity to present a social reality in which constant change is necessary. By indicating an external demand through the anecdotal citing of rivals that have 'lost' to Melbourne, the government, quangos and media have presented these events as important assets for the people of Victoria whilst reinforcing the 'natural' competitive functioning of social life.

\section{Reducing public consultation}

A lack of public consultation was often evident when sporting decisions were made. To justify this lack of consultation a number of arguments were used. Firstly, key decisionmakers expressed the need to keep plans secret from rivals as an important strategy for acquiring events:

... you should [give out publicly] as much information ... as you can that doesn't 
disadvantage the state ... We deal in the commercial world ... I really don't think anyone wants to keep stuff secret, even my political opponents. (J Pandazopolous, personal communication, 17 April 2013)

Pandazopolous explained that politicians have a desire to be open in their actions; however, the structure of the bureaucratic field, which has been infused with neoliberal commercial mechanisms, prevents full transparency. Harvey (1989) explains that publicprivate partnerships occupy a central facet of the urban entrepreneurial strategy in which traditional civic boosterism is integrated with the use of local powers to attract external sources of funding, new investments and avenues of employment. However, commercial confidentiality agreements, frequently cited as requirements of contracts between the state and private parties involved in sporting developments, have reduced public knowledge of investments and limited opportunities for public debate, whilst ensuring the protection of private interests. Paradoxically, non-transparency of price and information contradicts the free-market economics presupposition of neoliberalism.

Secondly, community consultation was often deemed to delay projects and framed as an obstruction to progress (Sandercock and Dovey, 2002). Kennett explained that his philosophy of governance was about output rather than consultation: 'Once the government decided to do something we governed. We weren't elected to form committees. People have the right every three or four years to throw out the government if they don't like what they're doing' (J Kennett, personal communication, 6 May 2013). Likewise, Kennett's successors adopted a 'fast-tracking' approach to key decisions; bypassing public consultation and ensuring the advancement of developments such as the Rectangular Stadium (Millar, 2005) and Commonwealth Games Athletes' Village (Tomazin, 2002).
Justin Madden, Labor's Commonwealth Games Minister, justified the fast-tracking: 'We need to have these facilities developed in time for the Commonwealth Games. With those traditional processes, they can be bogged down over time and thus delayed and not built on time' (cited in Tomazin, 2002: 2). In an attempt to demonstrate public consultation, Madden included representatives from the community on the Commonwealth Games Community Liaison Committee. However, as the Royal Park Protection Group expressed at the time, 'This is a complete misnomer as there are only 5 community representatives out of 24 who are mainly drawn from private enterprise and government departments' (RPPG, 2004: 1). As such, the structure of this public-private statutory authority appeared to favour private/commercial interests. Indeed, a number of scholars have illustrated the weaknesses inherent in the public consultation procedures, which are often skewed to support commercial interests (Fishkin, 2006; Scherer, 2011). While the Kennett government and those that followed have been criticised for a lack of consultation, Sandercock and Dovey (2002) assert that the fast-tracking approach was actually initiated by the Cain Labor government of the 1980s through its Major Projects Unit, and thus appears to be associated with the 'competitive city' environment rather than a specific political style. Despite neoliberalism's argument for minimal state intervention beyond protection of property and contracts, in Melbourne the state has been an active player in the creation of the sport city to ensure its competitiveness.

Lastly, the public's voice was considered to be appropriately substituted by quangos and 'expert panels'. Cahill and Bedner (2005) claim that the Kennett government replaced consultation with persuasion, choosing to spend funds on promoting its vision through advertising campaigns rather 
than seeking public opinion. In keeping with its 'free market' approach, the Kennett government, and those following, tended to adopt a strategy of putting projects out to tender and employing a quango, or panel of experts, to make recommendations:

When we decided to build something ... we invariably put it out to a public competition ... we accepted the decision of the expert committee ... So when I say we had no consultation, we governed but we tried to employ the best people around us to actually do the work and make a lot of the decisions. (J Kennett, personal communication, 6 May 2013)

As such, the government accepted the expert panel's voice as a sufficient substitute for public opinion and thus reduced the impact of public consultation.

Throughout the past three decades, the public's voice has been diminished by reducing consultation on the planning processes of major events through the signing of commercial confidentiality agreements, fasttracking decisions through bypassing public consultation and/or employing quangos to make decisions on behalf of the public. This reduction in public voice and knowledge has allowed the Victorian state to shape a corporate-friendly environment.

\section{State regulation: Quangos}

Quangos have occupied a significant role in creating this corporate-friendly environment. Even a cursory analysis of the aims of prominent sporting quangos, such as the MOPT and Australian Grand Prix Corporation, elucidate an emphasis on 'profit' generation, rather than social wellbeing (AGPC, 2014; MOPT, 2014). The power bestowed upon these quangos illustrates the re-regulatory power of the neoliberal state. For example, government-authorised exemptions from state heritage, environmental and freedom of information laws have permitted quangos to fast-track sporting infrastructure and engage in commercial activity, while increased 'security' powers and anti-disruption laws have limited the effect of public resistance (see Millar, 2006; Lowes, 2004; Tomazin, 2002). Moreover, these quangos, operating at arm's length from the government with minimal responsibility to the public in terms of consultation and democratic structures (Winter and Brooke, 1993), often operated under government control:

Most of those bodies are run by governmentappointed committees under an Act of Parliament ... and government influence/direction is there to be used if they want to ... the Melbourne and Olympic Parks Trust, they are beholden to the government, not just for money, but they can be directed ... [governments] don't do it with a sledgehammer, they do it by osmosis almost, it's conveyed what the government wishes and the body, it complies. (J Cain II, personal communication, 16 April 2013)

Cain's use of the term 'osmosis' is rather apt for describing this hegemonic process of coercion and consent. That is, the political and urban elite occupy influential positions and are thus able to determine the direction of the 'game' by constructing (consciously and subconsciously) a social reality that 'naturalises' the market (Bourdieu, 1998b). The perceived process of 'osmosis', rather than a sledgehammer, occurs as the neoliberal state regulates the market to suit the interests of the urban elite. The neoliberal promises to increase economic growth and profit, however, are not always evident. Indeed the F1GP, consistently criticised for generating an economic loss (Gordon, 2007; Herald Sun, 2013), has been retained under the premise that it supports the branding of Melbourne - whilst undoubtedly generating significant profit for the private corporations associated with the event.

The creation of a corporate-friendly environment through re-regulation by the state is 
an important element of the neoliberal agenda, but the success of neoliberalism relies on embedding the market as a normative logic of organising social, cultural and economic daily practices. In the next section we discuss how sport serves as 'cultural glue' which binds the neoliberal agenda to the daily, marketdriven practices of Melburnians.

\section{Sport as neoliberal 'cultural glue'}

We have demonstrated that, in the case of Melbourne, neoliberalism is an 'invasion' from above; we now need to expand on how it is also an invasion from within. The pervasiveness of sport in the Melbourne context has the illusory capacity to be of and for the people. Sport, in the neoliberal sense, is more than just bread and circuses. The standard logic of bread and circuses is that sport provides entertainment and distraction from the day-to-day problems of existence. However, rather than merely a tool to divert attention, sport in Melbourne is a vehicle to gain consent and legitimacy for a particular market logic, indeed to create the adhesive properties whereby the 'cultural glue' can actually bind. It does this through individual bodies in several ways, namely through 'doing' and 'consuming' sport.

Elite sport can offer those from the margins the potential pathway to the centre, a form of social mobility. Sport does not only discipline, it legitimises and affirms a meritocracy, one that those from the margins may apparently win in. As Hartmann (2012: 1015) observes, sport is a 'near perfect model' of neoliberal ideologies. There is nothing better than the 'self-made' woman, from rags to riches, to endorse the neoliberal myth. Such sporting biographies endorse the 'free' market as the fairest whilst ignoring what Wacquant (2004b) discovered in his boxing days, that those who made it already possessed a certain habitus that gave them the capacity of self-discipline, not to mention the physical skill, demanded by the ring. The self-made athlete obscures the reality of the swelling underclass beneath them, with whom they have all and nothing in common: all, in the sense that the ethno-class identity conflates individuals to a category; and nothing, in the sense that the life history of each at the embodied level could not be more different. Hence those 'rare as hen's teeth' success stories provide some of the illusio, but never a 'seat at the table', as the habitus required at the 'big end' is not in their armoury and the physical capital they have maximised is always limited compared with the cultural and social capital of the elites.

The illusio is compelling though, as its logic has very real structuring effects on the life choices of particular ethno-class fractions of the community. It should be noted that the model of talent identification for elite sport taps directly into the vast areas of grassroots sports organisations. This is evidenced not only by the massive overrepresentation of certain ethnicities in elite sport (Hallinan and Judd, 2009; McDonald et al., 2018), but more so through the enormous numbers who embark on the same pathway but never make it. Sport becomes a vehicle for social mobility, but far more likely social servility, as sport programmes operate as forms of 'sportfare' (McDonald et al., 2018: 12). These sports operate simultaneously as 'labour development, behavioural intervention and educational pathway' (McDonald et al., 2018: 3), where the possibility of making it seems to always eclipse the probability (Besnier, 2015). From an embodied perspective, neoliberalism literally recolonises the bodies of minority ethnicity as 'strategic resources and national objects to be organised, governed and manipulated for market advantage' (Walsh, 2014: 295-296).

Coupled to this are the other ways in which sport is consumed and how the collective effervescence of sporting events, which draw on public money and land to exist, 
somehow become dissociated from similar concerns that draw on public funds such as health and education. Sport is such effective 'cultural glue' because (unlike health, affordable housing and education, which become a private concern or individual 'conditions') it does not become a concern. As one walks to the stadium and enjoys the ease of access, the centrality of the amenity, the buzz of the crowd, one is not thinking that such funds could have created a comparable experience in education or welfare. The embodied nature of watching sports means that the 'cultural glue' originates from individual emotions generated from cheering on the team. The collective effervescence creates bonds that adhere to other fans and, as such, forms imagined communities that support a tribalism based on loyalty to team location and/or player origins that in truth does not exist anymore.

Simultaneous to the emotional condition, sporting events also establish and legitimise the punitive right hand of the state. This is achieved through the securitisation of sporting events (Schimmel, 2012). The high visibility of police and security firms, the construction of perimeter fencing, bag searches, metal detectors, surveillance cameras and public announcements to be vigilant, all contribute to a lived experience that reinforces the role of the neoliberal state. Backed by a sport media that controls large portions of the daily newsfeed, the cultural and historical 'significance' of sport to Melbourne's identity, and sporting events that literally mark social calendars in each season, it is little wonder then that the conditions are favourable for sporting entrepreneurs to continue to thrive.

\section{Conclusion}

Elite sport serves as a form of 'cultural glue' which has supported the Victorian
Government's neoliberal agenda of creating an environment conducive to commercial activity; that is, the sanctioning of urban sportscapes and public resources to permit and encourage 'consumption-oriented capital accumulation' (Silk and Andrews, 2012: 127). The ability to define the public interest allows the state to construct a social world which reflects the interests of those richest in various forms of capital (Bourdieu, 1998a). In Melbourne, the sporting urban entrepreneurial strategy to (re)produce the 'sport city' identity has led to the implementation of neoliberal practices, such as commercially sensitive contracts between the state and private sector which limit public knowledge, and the passing of legislation to prevent dissident activities at corporate-friendly events. Four themes emerged from our analysis of the sporting developments in Melbourne over the course of three decades: i) the Victorian state has consistently devoted significant public resources to sporting urban entrepreneurial activities; ii) external cities have been positioned as rivals to enhance the public's belief in the value of sports events/infrastructure which has also served to normalise 'competition'; iii) the Victorian public have largely been excluded from the decision-making process; and iv) the state, through the use of quangos and laws to permit commercial activity, has regulated Melbourne to create a corporate-friendly environment. Of importance, as Wacquant (2004a: 8) expresses, is that:

[T]he state does not exist only 'out there,' in the guise of bureaucracies, authorities, and ceremonies: it also lives 'in here,' ineffaceably engraved in all of us in the form of the statesanctioned mental categories acquired via schooling through which we cognitively construct the social world.

That is, citizens have been socialised to consent to the actions and visions of the state through education and state-sanctioned 
cultural activities, such as sport. Together with the redefinition of the public interest in market-like principles, the premise that consuming elite sport is an important element of 'being Victorian', or embodied cultural capital (Bourdieu, 1986), has served to reinforce a neoliberal doctrine of economic productivity through individualisation, competition, meritocracy and consumerism. In this manner, sport has become a form of 'cultural glue' which fastens the values and motives of the public to neoliberal ideologies.

\section{Acknowledgements}

The authors would like to acknowledge the anonymous reviewers for their insightful and constructive comments on earlier versions of this article. Anonymised interview transcripts from participants who consented to data sharing, plus other supporting information, are available from the lead author upon request.

\section{Declaration of conflicting interests}

The author(s) declared no potential conflicts of interest with respect to the research, authorship, and/or publication of this article.

\section{Funding}

The author(s) received no financial support for the research, authorship, and/or publication of this article.

\section{ORCID iD}

Alistair John (iD) https://orcid.org/0000-00019019-1944

\section{References}

Agger B (1992) Cultural Studies as Critical Theory. London: The Falmer Press.

AGPC (2014) Annual report 2013-2014. Available at: http://www.grandprix.com.au/docs/2014/ annual-report/AGPC-2014-ANNUAL-REPORT. pdf (accessed 25 July 2015).
Besnier N (2015) Sports mobilities across borders: Postcolonial perspectives. The International Journal of the History of Sport 32(7): 849-861.

Bourdieu P (1986) The forms of capital. In: Richardson JG (ed.) Handbook of Theory and Research for the Sociology of Education. New York: Greenwood Press, pp. 241-258.

Bourdieu P (1998a) Neo-liberalism, the Utopia (becoming a reality) of unlimited exploitation. In: Bourdieu P (ed.) Acts of Resistance: Against the New Myths of Our Time. Translated by R Nice. Cambridge: Polity Press, pp. 94-105.

Bourdieu P (1998b) The left hand and the right hand of the state. In: Bourdieu P (ed.) Acts of Resistance: Against the New Myths of Our Time. Translated by $\mathrm{R}$ Nice. Cambridge: Polity Press, pp. 1-10.

Braun V and Clarke V (2006) Using thematic analysis in psychology. Qualitative Research in Psychology 3(2): 77-101.

Cahill D and Bedner S (2005) Neo-liberal think tanks and neo-liberal restructuring: Learning the lessons from Project Victoria and the privatisation of Victoria's electricity industry. Social Alternatives 24(1): 43-48.

Canovan M (1999) Trust the people! Populism and the two faces of democracy. Political Studies 47(1): 2-16.

Coakley J (2011a) Ideology doesn't just happen: Sports and neoliberalism. Curitiba 1(1): 67-84.

Coakley J (2011b) Youth sports: What counts as 'positive development?' Journal of Sport and Social Issues 35(3): 306-324.

Considine M and Costar B (1992) Introduction. In: Considine $\mathrm{M}$ and Costar B (eds) Trials in Power: Cain, Kirner and Victoria 1982-1992. Melbourne: Melbourne University Press, pp. 1-10.

Department of Social Services (2011) The People of Australia: Australia's Multicultural Policy. Canberra: Department of Social Services. Available at: http://apo.org.au/node/27232 (accessed 4 July 2018).

Dingle T and O'Hanlon S (2009) From manufacturing zone to lifestyle precinct: Economic restructuring and social change in inner Melbourne, 1971-2001. Australian Economic History Review 49(1): 52-69. 
Du Gay P (1997) Introduction. In: Du Gay P (ed.) Production of Culture/Cultures of Production. London: Sage Publications, pp. 1-10.

Du Gay P, Hall S, Janes L et al. (1997) Doing Cultural Studies: The Story of the Sony Walkman. London: Sage Publications.

Engels B (2000) City make-overs: The place marketing of Melbourne during the Kennett years, 1992-99. Urban Policy and Research 18(4): 469-494.

Fishkin JS (2006) Strategies of public consultation. The Integrated Assessment Journal: Bridging Sciences \& Policy 6(2): 57-72.

Gold JR and Gold MM (2008) Olympic cities: Regeneration, city rebranding and changing urban agendas. Geography Compass 2(1): $300-318$.

Gordon J (2007) Anger as auditor queries GP's value. The Age, 24 May, p. 6.

Gratton C and Henry IP (eds) (2001) Sport in the City: The Role of Sport in Economic and Social Regeneration. London: Routledge.

Grix J and Houlihan B (2014) Sports mega-events as part of a nation's soft power strategy: The cases of Germany (2006) and the UK (2012). The British Journal of Politics and International Relations 16(4): 572-596.

Hall CM (2006) Urban entrepreneurship, corporate interests and sports mega-events: The thin policies of competitiveness within the hard outcomes of neoliberalism. The Sociological Review 54(s2): 59-70.

Hallinan C and Judd B (2009) Race relations, Indigenous Australia and the social impact of professional Australian football. Sport in Society 12(9): 1220-1235.

Hartmann D (2012) Beyond the sporting boundary: The racial significance of sport through midnight basketball. Ethnic and Racial Studies 35(6): 1007-1022.

Harvey D (1989) From managerialism to entrepreneurialism: The transformation in urban governance in late capitalism. Geografiska Analer 71(1): 3-17.

Herald Sun (1994) The battle for Albert Park. Herald Sun, 17 May, p. 14.

Herald Sun (2006) Cynical games. Herald Sun, 10 March, p. 22.

Herald Sun (2013) Bernie Ecclestone's Formula One Grand Prix licence fee costs taxpayers millions. Available at: https://www.heraldsun. com.au/news/opinion/bipartisan-secrecy-getsa-red-flag/news-story/f863d6d649b250e608fcf 320f02be661 (accessed 12 December 2018).

Higginbottom N (2009) \$500m secures our Open. Herald Sun, 27 January, p. 12.

Hilgers M (2011) The three anthropological approaches to neoliberalism. International Social Science Journal 61: 351-364.

Hilgers M (2013) Embodying neoliberalism: Thoughts and responses to critics. Social Anthropology 21(1): 75-89.

Holmes J (1995) Victoria: State enterprise and Labor in the Eighties. In: Peachment A (ed.) Westminster Inc: A Survey of Three States in the 1980s. Sydney: Federation Press, pp. 1-36.

Houston C (2009) Brumby to dig deep to secure Open. The Age, 18 January, p. 1.

Hubbard P (1996) Urban design and city regeneration: Social representation of entrepreneurial landscapes. Urban Studies 33(8): 1441-1461.

Jessop B (2013) Putting neoliberalism in its time and place: A response to the debate. Social Anthropology 21(1): 65-74.

John A, Stewart B and McDonald B (2013) Mixed doubles: Political hegemony, urban entrepreneurialism and the Australian Open Tennis Championships. The International Journal of the History of Sport 30(2): 162-178.

Kellner D (2011) Cultural studies, multiculturalism, and media culture. In: Dines $G$ and Humez JM (eds) Gender, Race, and Class in Media: A Critical Reader. 3rd edn. London: Sage Publications, pp. 7-18.

Kroen A and Goodman R (2012) Implementing metropolitan strategies: Lessons from Melbourne. International Planning Studies 17(3): 303-321.

Lowes M (2004) Neoliberal power politics and the controversial siting of the Australian Grand Prix motorsport event in an urban park. Society and Leisure 27(1): 69-88.

McDonald B, Rodriguez $\mathrm{R}$ and George $\mathrm{J}$ (2018) 'If it weren't for rugby I'd be in prison now': Pacific Islanders, rugby and the production of 'natural' spaces. Journal of Ethnic and Migration Studies. Published online 27 June 2018. DOI: 10.1080/1369 183X.2018.1492909. 
Mayne S (2009) The Jeff Kennett treatise that helped tip him out. The Mayne Report. Available at: http://www.maynereport.com/articles/ 2007/11/02-2252-3030.html (accessed 23 April 2014).

Millar R (2005) Good Gosch! Critics swoop as Magpies given new paddock. The Age, 31 October, p. 3.

Millar R (2006) Camping, hunting and heckling cut from events program. The Age, 13 March, p. 4.

Miller T (2012) A distorted playing field: Neoliberalism and sport through the lens of economic citizenship. In: Andrews DL and Silk ML (eds) Sport and Neoliberalism: Politics, Consumption and Culture. Philadelphia, PA: Temple University Press, pp. 23-37.

Ministerial Council on Immigration and Multicultural Affairs (2007) A national action plan to build on social cohesion, harmony and security. Canberra: DIAC.

MOPT (2014) Melbourne \& Olympic Parks annual report 2014. Available at: http://www.mopt.co m.au/wp-content/uploads/2012/11/MOP0156Annual-Report_2013-14_WEB.pdf (accessed 21 May 2015).

Nadel D and Ryan G (eds) (2015) Sport in Victoria: A History. Melbourne: Ryan Publishing.

Neales S and Magazanik M (1994) Move GP or lose it, 10,000 tell Kennett. The Age, 16 May, p. 1.

Ortiz D, Myers D, Walls E et al. (2005) Where do we stand with newspaper data? Mobilization: An International Quarterly 10(3): 397-419.

Owen K and Hansen K (1998) \$65m arena gets green light. Herald Sun, 21 May, p. 3.

Papps N (2000) State seeks 10 more years of GP. Herald Sun, 1 March, p. 7.

Parliament of Victoria (1984) Victoria: The Next Step: Economic Initiatives and Opportunities for the 1980s. Melbourne: Government Printer.

Parliament of Victoria (1985) Parliamentary Debates: Legislative Council: Official Hansard. Melbourne: Government Printer.

Parliament of Victoria (2001) Commonwealth Games Arrangement Act 2001. 57/2001. Available at: http://www.legislation.vic.gov.au/ Domino/Web_Notes/LDMS/PubStatbook.nsf/ f932b66241 ecf 1 b7ca256e92000e23be/884c9d 17
082acbb8ca256e5b00213f4b/\$FILE/01-057a.pdf (accessed 19 February 2014).

Pinder S (1993) Driving ace to plan GP event. Herald Sun, 18 December, p. 17.

Premier of Victoria (2016) Melbourne - The Sporting Capital of the World. Available at: https://www.premier.vic.gov.au/melbournethe-sporting-capital-of-the-world/ (accessed 16 February 2019).

Pro GP (1994) Letters to the editor. Herald Sun, 20 May, p. 18.

Rood D (2008) Facelift at Melbourne Park to keep Open on side. The Age, 18 January, p. 6.

RPPG (2004) Annual report of the Royal Park Protection Group (RPPG). Available at: http://royalparkprotect.com.au/wp-content/ uploads/2013/02/2004-Annual-Report.pdf.pdf (accessed 18 March 2015).

Sam M and Hughson J (eds) (2011) Sport in the City: Cultural Connections. London: Routledge.

Sandercock L and Dovey K (2002) Pleasure, politics, and the 'public interest': Melbourne's riverscape revitalization. Journal of the American Planning Association 68(2): 151-164.

Scherer J (2011) Olympic villages and large-scale urban development: Crises of capitalism, deficits of democracy? Sociology 45(5): 782-797.

Schimmel KS (2006) Deep play: Sports megaevents and urban social conditions in the USA. The Sociological Review 54(s2): 160-174.

Schimmel KS (2012) Neoliberal redevelopment, sport infrastructure, and the militarization of U.S. urban terrain. In: Andrews DL and Silk ML (eds) Sport and Neoliberalism: Politics, Consumption and Culture. Philadelphia, PA: Temple University Press, pp. 160-176.

Shaw K (2013) Docklands dreamings: Illusions of sustainability in the Melbourne docks redevelopment. Urban Studies 50(11): 2158-2177.

Silk ML and Andrews DL (2012) The governance of the neoliberal sporting city. In: Andrews DL and Silk ML (eds) Sport and Neoliberalism: Politics, Consumption and Culture. Philadelphia, PA: Temple University Press, pp. 127-142.

Smith J and Whitworth F (1995) Save Albert Park! Green Left Weekly 206. 10 October. Available at: www.greenleft.org.au/node/ 10595 (accessed 6 July 2016). 
Spaaij R (2012) Beyond the playing field: Experiences of sport, social capital, and integration among Somalis in Australia. Ethnic and Racial Studies 35(9): 1519-1538.

Spiller M (2014) Social justice and the centralisation of governance in the Australian metropolis: A case study of Melbourne. Urban Policy and Research 32(3): 361-380.

Tennis Australia Magazine (1983) Kooyong problems. August, pp. 7-9.

The Age (2010) Sporting capital welcomes two new clubs. 5 August, p. 16.

Tomazin F (2002) No impact study for Parkville site. The Age, 25 October, p. 2.

VMEC (2015) About. Available at: http:// www.vmec.com.au/about\#!/about (accessed 12 December 2015).

Wacquant L (2004a) Pointers on Pierre Bourdieu and democratic politics. Constellations 11(1): $3-15$.

Wacquant L (2004b) Body \& Soul. Oxford: Oxford University Press.

Wacquant L (2010) Crafting the neoliberal state: Workfare, prisonfare, and social insecurity. Sociological Forum 25(2): 197-220.

Wacquant L (2012) Three steps to a historical anthropology of actually existing neoliberalism. Social Anthropology 20(1): 66-79.
Wacquant L (2014) Marginality, ethnicity, and penality in the neoliberal city: An analytical cartography. Ethnic and Racial Studies 37(10): 1687-1711.

Walsh J (2014) The marketization of multiculturalism: Neoliberal restructuring and cultural difference in Australia. Ethnic and Racial Studies 37(2): 280-301.

Watt P (2013) 'It's not for us': Regeneration, the 2012 Olympics and the gentrification of East London. City 17(1): 99-118.

White L and Economou N (1999) The fourth estate and the Kennett government. In: Costar B and Economou N (eds) The Kennett Revolution: Victorian Politics in the 1990s. Sydney: University of NSW Press, pp. 27-36.

Winter I and Brooke T (1993) Urban planning and the entrepreneurial state: The view from Victoria, Australia. Environment and Planning C: Government and Policy 11(3): 263-278.

Wright A (2012) Taxpayers in dark over costs to keep the Australian Open in Melbourne. Herald Sun. Available at: http://www.herald sun.com.au/news/victoria/taxpayers-in-darkover-costs-to-keep-the-australian-open-in-melbourne/story-e6frf7kx-1226424867620 (accessed 7 May 2014). 